\title{
Effect of Kirganelia reticulata extract on Human Embryonic Kidney cells with evidence on morphological changes
}

\author{
Madhurima Ghosh $^{1}$, Jhinuk Chatterjee ${ }^{2}$, V. Krishnamurthy ${ }^{2}$ \\ ${ }^{1}$ Department of Biotechnology, PES Institute of Technology, Bangalore - 560085, India. \\ ${ }^{2}$ Department of Biotechnology, PES University, Bangalore - 560085, India.
}

\section{ARTICLE INFO \\ Article history: \\ Received on: $12 / 03 / 2018$ \\ Accepted on: 13/08/2018 \\ Available online: 30/09/2018}

Key words:

Phytochemicals, Kirganelia,

HEK-293, Cell morphology,

Anti-Proliferative.

\begin{abstract}
Kirganelia reticulata has been proven to have cytotoxic activities. The aim of this study is to demonstrate the antiproliferative activity of the methanolic extract of $K$. reticulata on Human Embryonic Kidney cells (HEK-293). Changes in cellular morphology of HEK-293 cells were evident at higher concentration and with an increase in time, which was supported by our experimental data. Our preliminary data suggest that $K$. reticulata methanolic extract has anti-proliferative activity.
\end{abstract}

\section{INTRODUCTION}

Phytochemicals refer to an extensive diversity of nonessential nutritive compounds with protective or disease preventive properties (Russo et al., 2010), produced by plants to protect themselves, and are not required by the human body for sustaining life. Recent research demonstrates that these chemical compounds can also protect humans against diseases. (Suresh et al., 2007). Some of the more commonly known phytochemicals include beta-carotene, ascorbic acid (vitamin C), folic acid, and vitamin E. Phytochemicals are promoted for the evidence that certain phytochemicals prevent and treat many health conditions, including heart disease, diabetes and high blood pressure (Michaud et al., 2000), and also prevent the formation, block the action on their target organs or tissue, act on cells to suppress substances that cause cancer development (Mehta and Pezzuto, 2002).

This framework has been valuable for the development of research on many different types of secondary plant metabolites

\footnotetext{
${ }^{*}$ Corresponding Author

Dr. Jhinuk Chatterjee, Assistant Professor, Department of Biotechnology, PES University, Bangalore-560085.E-mail: jhinukchatterjee@pes.edu
}

that show biological activity in mammals, and it continues to provide a valuable approach for the classification of these compounds and their effects. The genus Phyllanthus L., one of the largest genera of Euphorbiaceae, is diverse in the morphology and chemical constituents. It is divided into 11 subgenera including Kirganelia, Cicca, Emblica, etc. The plants of this genus have been used in folk medicine to treat kidney and urinary bladder disturbances, intestinal infection, diabetes and hepatitis B (Unander et al., 1990). Some laboratory studies in cell cultures and animals have shown that certain phytochemicals have some activity against cancer cells or tumors (Lampronti et al., 2003). Researchers have also shown much interest in phytochemical supplements. However, despite the promising results from experimental studies, only a limited number of clinical trials are ongoing to assess the therapeutic efficacy of these molecules.

Kirganelia reticulata, is a locally available plant in Savanadurga forest of Karnataka. This plant is also found in tropical areas of Indian sub-continent and China (Ghani, 2003). According to the folklore, the plant has essentially been a part traditional medication for the treatment of gastric complaints (Joshi et al., 1991), diuretic and cooling medicine, to cure diarrhea in infants, treat sore eyes and superficial burns (Chopra 
et al., 1956). The anti-diabetic activity was also claimed and validated in tribal areas (Kumar et al., 2008). Morphological and microscopic characteristics of the leaves of Kirganelia reticulata were established, and anti-bacterial potential of the leaf extract has been evaluated (Shruthi et al., 2010). This plant has proved to potentially possess cytotoxic and antitumor activities. This was demonstrated using brine shrimp lethality assay and crown gall tumor inhibition assay (Reddy et al., 2014).

Numerous cell lines have been used as a model cell line for the detection of cytotoxicity in cells. HEK-293, Caco-2, HT-29, A549, has been majorly used for detection of morphological anomalies. Changes in cellular morphology, cell viability, cell membrane integrity, reactive oxygen species levels, mitochondrial membrane potential, cell death (apoptosis and necrosis), and the DNA damage were observed (Selvaraj et al., 2014; Kataria et al., 2011). Dose-dependent inhibition on proliferation and viability of the cells shows the cytotoxic activity of the active compound. In-vitro verification of cytotoxic effects on HEK293 and inhibitory effects on the proliferation has been taken as a method to validate the present study, where we aim to evaluate and investigate methanolic leaf extract of $K$. reticulata for antiproliferative effect in adherent cells (HEK-293).

\section{MATERIAL AND METHODS}

\section{Materials and reagents}

All chemicals were obtained from Sigma Aldrich (St. Louis, Missouri, USA) unless otherwise indicated.

RPMI-1640, Trypsin and Antibiotic-Antimycotic (100X) were purchased from Thermo Fisher Scientific (Carlsbad, CA, USA). 0.22-micron syringe filters were obtained from Millipore Ireland Ltd. Cell Culture plastic ware was obtained from Greiner Bio-One International GmbH, Austria.

\section{Cell line}

Human Embryonic Kidney cell line, HEK-293 was obtained from National Centre for Cell Science, Pune, India (tested as Mycoplasma negative), and was cultured in a T-25 and T-75 cell culture flask using RPMI-1640 medium supplemented with $10 \%$ FBS and antibiotics (1X Antibiotic-Antimycotic). The cells were incubated at $37^{\circ} \mathrm{C}$ in a humidified incubator containing $5 \% \mathrm{CO}_{2}$ and subcultured when the confluence of the flask reaches $80 \%$ or every 72 hours, whichever is early using a starting inoculum of $0.3 \times 10^{5}$ cells $/ \mathrm{ml}$.

The design of the experiment was set up for 24-well tissue culture plate in triplicate, and each well was seeded with $0.3 \times 10^{5}$ HEK-293 cells in $1 \mathrm{ml}$ RPMI-1640 media supplemented with $10 \%$ FBS. The tissue culture plate was incubated in a $\mathrm{CO}_{2}$ incubator for 24 hours for the HEK-293 cells to completely adhere to the plate surface and to confirm the sterility of the culture plate. The HEK-293 cells were found to be completely attached with $60 \%$ confluency after 24 hours. The tissue culture plate was ready for the treatment with different concentrations of crude extract of Kirganelia reticulata.

\section{Preparation of Kirganelia reticulata leaf extract}

10 grams of ground leaf powder from Kirganelia reticulata was subjected to $150 \mathrm{ml}$ of $70 \%$ methanol extraction in a Soxhlet extractor at $70^{\circ} \mathrm{C}$ for 4 hours. Post filtration, the solvent was evaporated using a rotary vacuum evaporator under a reduced pressure condition and at a temperature below $50^{\circ} \mathrm{C}$. The dried methanolic extracts were stored in a refrigerator for future phytochemical analysis (Reddy et al., 2014). 24 hours prior to the set-up of the experiment, the extract was dissolved in RPMI-1640 at a stock concentration of $2 \mathrm{mg} / \mathrm{mL}$, filtered through a 0.2 -micron syringe filter and a sample was tested for sterility over-night in a $\mathrm{CO}_{2}$ incubator. Once sterility was confirmed, the extract was used for the study.

\section{Experimental design for determination of antiproliferative activity}

In the present study, we have determined the antiproliferative activity of the extract on HEK-293 cells based on confluency percentage. For adherent cells, the confluency is the percentage of area covered by the cells. For example, 50\% confluency means, the area covered by the cells and the empty spaces in the plate look similar under the microscope. $100 \%$ confluency means, there won't be any spaces in between the cells under microscopic observation. Once the sterility of the stock (2 $\mathrm{mg} / \mathrm{ml}$ ) of the methanolic extract of $K$. reticulata was confirmed and the HEK-293 cells were found to be at $\sim 60 \%$ confluency with expected morphology, the design of experiment was set up in triplicates in 24-well tissue culture plates. The seeding density of cells was $0.3 \times 10^{5}$ cells $/ \mathrm{ml}$ per well. The cells were treated with seven different concentrations from 0 (control, with no extract added) to $1000 \mu \mathrm{g} / \mathrm{mL}$ of the methanolic extract of $K$. reticulata and observed over a period of 1, 23 and 24 hours. The concentrations of the methanolic extract that the cells were tested for are $10 \mu \mathrm{g} /$ $\mathrm{ml}, 25 \mu \mathrm{g} / \mathrm{ml}, 50 \mu \mathrm{g} / \mathrm{ml}, 100 \mu \mathrm{g} / \mathrm{ml}, 250 \mu \mathrm{g} / \mathrm{ml}, 500 \mu \mathrm{g} / \mathrm{ml}$ and 1000 $\mu \mathrm{g} / \mathrm{ml}$. The volume of extract added per well was calculated in reference to the stock concentration. The confluence of HEK-293 cells was observed under $20 \mathrm{X}$ magnification. The proliferation of the HEK-293 cells was assessed by confluency percentage.

\section{Cell morphology analysis}

Morphological changes of HEK-293 cells were closely monitored, noted and images were captured. Under the phasecontrast microscope, the untreated cells exhibited typical growth patterns and a smooth, flattened morphology with normal nuclei. When treated with plant extract at different concentrations, the cells exhibit apoptotic morphological changes with cytoplasmic blebbing in some cases, and detachment from the surface (Merlin et al., 2010).

\section{RESULTS}

\section{Kirganelia reticulata extract exhibit anti-proliferative activity}

Post 1-hour treatment with $>250 \mu \mathrm{g} / \mathrm{ml}$ of $K$. reticulata, the HEK-293 cells were found to round off and detach from the adherent surface. Also at the end of 24 hours, it was observed that the confluence levels have gone down to $<10 \%$ as against control $(0 \mu \mathrm{g} / \mathrm{ml})$ which is at $90 \%$ confluency. When incubation time was prolonged to 24 hours, the HEK-293 cells looked completely healthy $<50 \mu \mathrm{g} / \mathrm{ml}$ with confluency at $>80 \%$. This has been clearly illustrated in Fig. 1. 


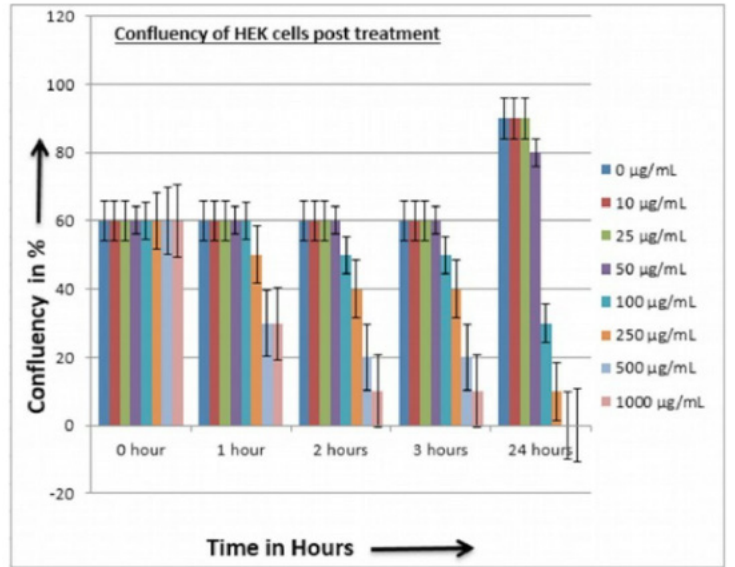

Fig. 1: Confluency of HEK-293 cells post treatment with $K$. reticulata extract.

\section{Morphological changes in HEK-293}

Cell morphology is an amicable visual tool to assess the toxicity in cells. HEK-293 cells-untreated and treated with different concentrations of $K$. reticulata, showed morphological changes. After completion of the treatment periods, the HEK-293 cells were observed under $20 \mathrm{X}$ magnification and images were taken for further analysis. Comparing the morphology of the control untreated HEK-293 cells with a lower concentration of $10-50 \mu \mathrm{g} / \mathrm{ml}$ up to 3 hours appeared similar. With the increase in concentration and increase in time (at 24 hours), cell shrinkage and decreased regularization of cells were observed. When treatment was more than 2 hours and the concentration was more than 100 $\mu \mathrm{g} / \mathrm{ml}$, cellular disintegration and a decrease in cell number and confluency was observed. Fig. 2 demonstrates the microscopic study, that with an increase in time and concentration, the gaps between HEK-293 cells increased.

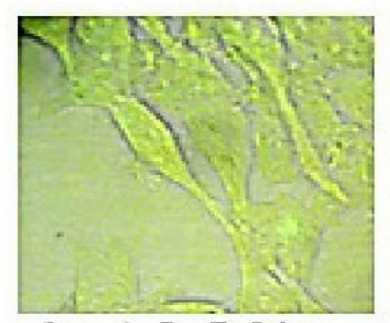

$0 \mu \mathrm{g} / \mathrm{mL} @ 0$ hour

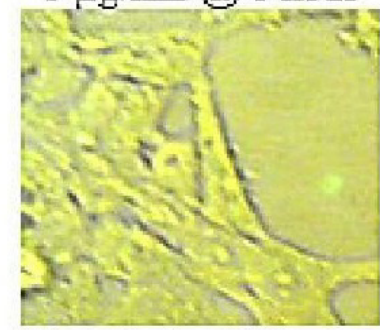

$25 \mu \mathrm{g} / \mathrm{mL} @ 0$ hour

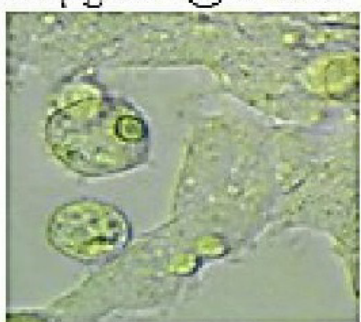

$100 \mu \mathrm{g} / \mathrm{mL} @ 3$ hours $100 \mu \mathrm{g} / \mathrm{mL}(Q) 4$ hours

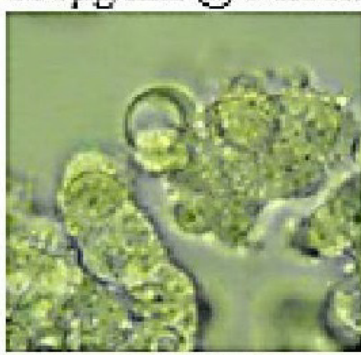

$500 \mu \mathrm{g} / \mathrm{mL} \propto 1$ hour
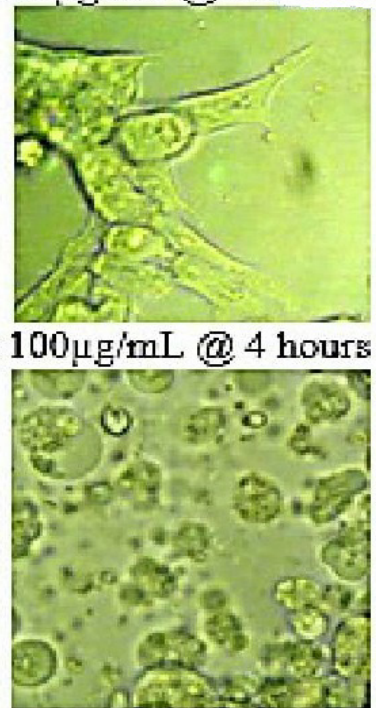
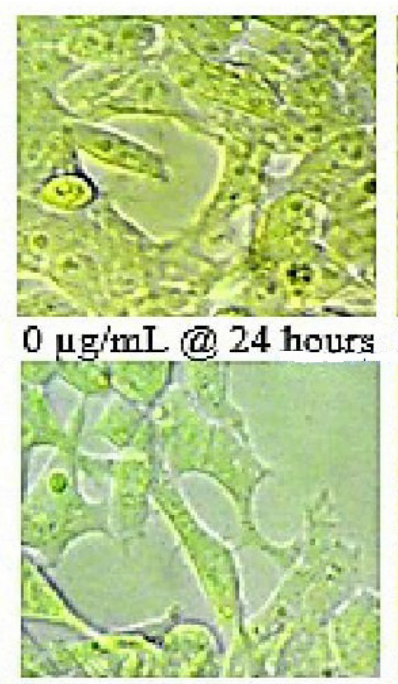

$25 \mu \mathrm{g} / \mathrm{mL}(2) 24$ hourg
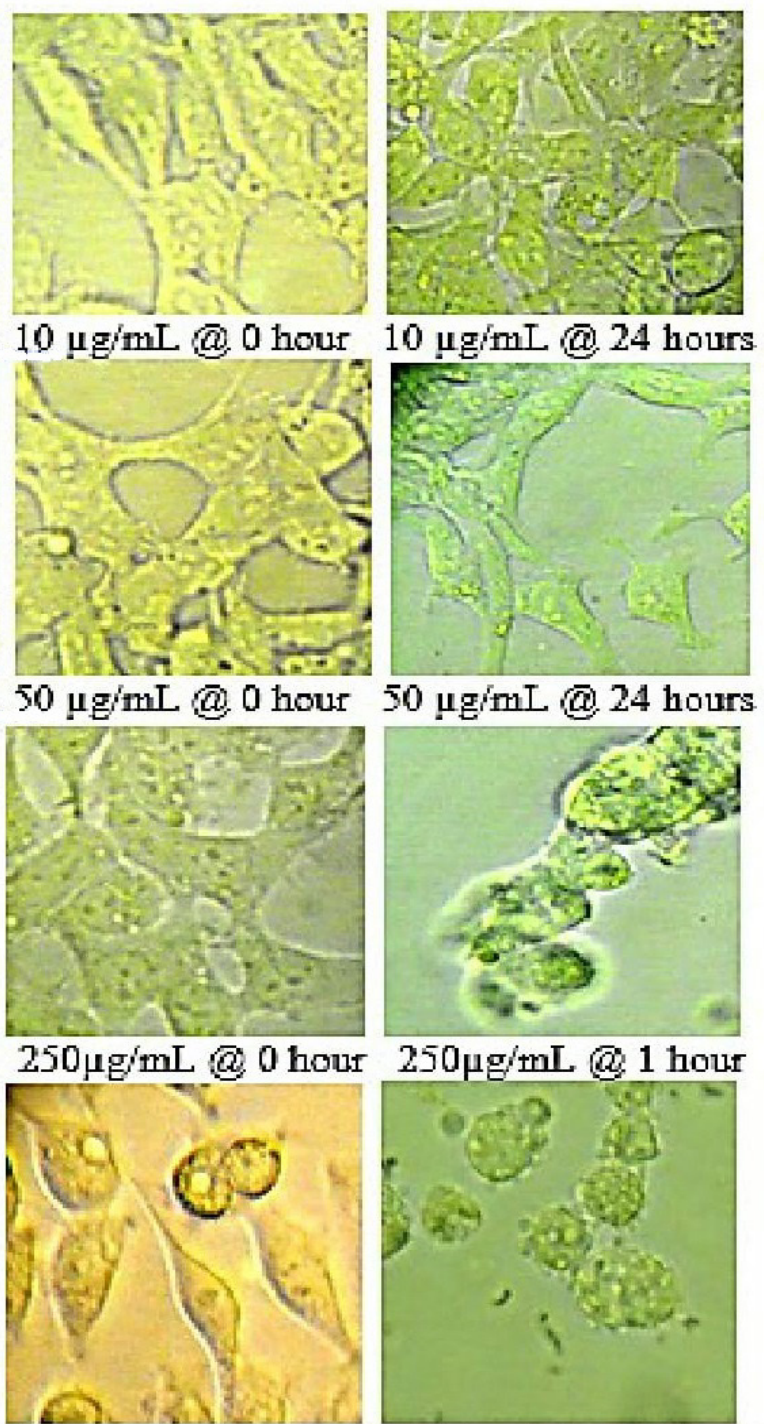

$1000 \mu \mathrm{g} / \mathrm{mL} @ 0$ hour $1000 \mu \mathrm{g} / \mathrm{mL}(\omega) 1$ hour

Fig. 2: Morphological changes of HEK-293 cells when exposed at various concentrations of $K$. reticulata extract for 24 hrs. 


\section{DISCUSSION}

The success of drugs against cancer is solely on the mechanism of apoptosis of cells. The search for more effective drugs with antiproliferative activity have interested researchers in the traditional medicines of different parts of the world. A strategical and thoughtfully induced anti-proliferation by inducing apoptosis of cancer cells is the new age therapy for tumor cells and cancerous cells (Lampronti et al., 2003; Haass-Koffler et al., 2012).

Kirganelia reticulata was successfully tested and proven to be cytotoxic and antitumor using crown gall inhibitory assay (Reddy et al., 2014). In the present study, the exposure of methanolic extract of $K$. reticulata significantly reduced the proliferation of cells.

Our study demonstrates the exposure of methanolic extract of $K$. reticulata causes morphological changes in HEK-293 cells at a higher concentration more than $50 \mu \mathrm{g} / \mathrm{mL}$ and with an increase in time. The loss of normal morphology began with 250 $\mu \mathrm{g} / \mathrm{mL}$ within 1 hour of treatment, where the cells were found to round off and lose the integrity (Haghparast et al., 2015). With the increase in exposure time and concentration of the extract, the cells retracted into a spherical shape and formed clusters in media after detachment from the surface (Guan et al., 2012; Joshi et al., 2013).

Thus, these findings add a new dimension on the methanolic extract of $K$. reticulata and t explore more on the potential of this phytochemical with anti-proliferative active compound towards cancer prevention (Sandercock et al., 2015).

\section{CONCLUSION}

In the present study, the exposure of methanolic extract of Kirganelia reticulata significantly reduced the proliferation of HEK-293 cells and causes morphological changes in cells at a higher concentration more than $50 \mu \mathrm{g} / \mathrm{mL}$ and with an increase in time.

\section{ACKNOWLEDGMENT}

The authors gratefully acknowledge Mr. Ravikumar A Reddy of Nitya Genomics Pvt Ltd, for providing the methanolic extract of Kirganelia reticulata, for conducting the study.

\section{REFERENCES}

Sandercock AM, Rust S, Guillard S, Sachsenmeier KF, Holoweckyj N, Hay C, Flynn M, Huang Q, Yan K, Herpers B, Price LS, Soden J, Freeth J, Jermutus L, Hollingsworth R, Minter R. Identification of anti-tumour biologics using primary tumour models, 3-D phenotypic screening and image-based multi-parametric profiling. Molecular Cancer, $2015 ; 14: 147$.

Joshi B, Barman I, Dingari NC, Cardenas N, Soares JS, Dasari RR, Samarendra Mohanty. Label-free route to rapid, nanoscale characterization of cellular structure and dynamics through opaque media. Scientific Reports, 2013; 3:2822.

Haass-Koffler CL, Naeemuddin M, Bartlett SE. An analytical tool that quantifies cellular morphology changes from three dimensional fluorescence images. Journal of Visualized Experiments, 2012; 66:e4233.

Chopra RN, Nayar SL, Chopra IC. 1956. Glossary of Indian medicinal plants (2 ${ }^{\text {nd }}$ Edition), New Delhi, India: CSIR.
Ghani A. 2003. Medicinal plants of Bangladesh, chemical constituents and uses ( $2^{\text {nd }}$ Edition), Asiatic Society of Bangladesh 345.

Kataria H, Shah N, Kaul SC, Wadhwa R, Kaur G. Water extract of ashwagandha leaves limits proliferation and migration, and induces differentiation in glioma cells. Evidence-Based Complementary and Alternative Medicine, 2011; 2011, ID 267614.

Joshi KC, Singh P, Mehta A. Crystalline components of the root of Phyllanthus reticulata. Journal of Indian Chemical Society, 1991; 58:102.

Kumar S, Kumar D, Deshmukh RR, Lokhande PD, More SN, Rangari VD. Antidiabetic potential of Phyllanthus reticulata in alloxaninduced diabetic mice. Fitoterapia, 2008; 79:21-23.

Mehta RG, Pezzuto JM. Discovery of cancer preventive agents from natural products: From plants to prevention. Current Oncology Reports, 2002; 4:478-486.

Michaud DS, Feskanich D, Rimm EB. Intake of specific carotenoids and risk of lung cancer in two prospective U.S. cohorts American Journal of Clinical Nutrition, 2000; 72(4):990-997.

Merlin NJ, Parthasarathy V, Santhoshkumar TR. Induction of apoptosis in human breast cancer cell line MCF-7 by phytochemicals from Gmelina asiatica. African Journal of Biotechnology, 2010; 9(28):44514456.

Lampronti I, Martello D, Bianchi N, Borgatti M, Lambertini E, Piva R, Jabbar S, Choudhuri MSK, Khan MTH, Gambari R. In vitro antiproliferative effects on human tumor cell lines of extracts from the Bangladeshi medicinal plant Aegle marmelos Correa. Phytomedicine, 2003; 10(4):300-308

Reddy RA, Madgaonkar V, Venkatesh RT, Bharathi R, Krishna Murthy V. Potential cytotoxic drug effects of secondary metabolites derived from selected medicinal plants of Savanadurga forest in Karnataka. International Journal of Pharmacy and Pharmaceuticals Sciences, 2014; 6(10):238-241.

Guan R, Kang T, Lu F, Zhang Z, Shen H, Liu M. Cytotoxicity, oxidative stress, and genotoxicity in human hepatocyte and embryonic kidney cells exposed to $\mathrm{ZnO}$ nanoparticles. Nanoscale Research Letters, 2012; 7(1):602

Russo M, Spagnuolo C, Tedesco I, Russo GL. Phytochemicals in Cancer Prevention and Therapy. Toxins, 2010; 2:517-551.

Suresh Kumar MA, Mangalam N, Hema PS, John M, Santhosh Kumar TR. Pinocembrin triggers Bax-dependent mitochondrial apoptosis in colon cancer cells. Mol Carcinogen, 2007; 46(3):231-241.

Haghparast SMA, Kihara T, Miyake J. Distinct mechanical behavior of HEK293 cells in adherent and suspended states. Peer J, 2015; 3:e1131.

Shruthi SD, Ramachandra YL, Padmalatha Rai S, Jha PK. Pharmacognostic of the leaves of Kirganelia reticulata Baill (Euphorbiaceae). The Asian and Australasian Journal of Plant Sciences and Biotechnology, 2010; 4(1):62-65.

Unander DW, Webster GL, Blumberg BS. Records of usage or assays in Phyllanthus (Euphorbiaceae) L. Subgenera Isocladus, Kirganelia, Cicca, Emblica. Journal of Ethnopharmacol, 1990; 30(3):233-64.

Selvaraj V, Bodapati S, Murray E, Rice KM, Winston N, Shokuhfar T, Zhao Y, Blough E. Cytotoxicity and genotoxicity caused by yttrium oxide nanoparticles in HEK293 cells. International Journal of Nanomedicine, 2014; 9:1379-1391.

How to cite this article:

Ghosh M, Chatterjee J, Krishnamurthy V. Effect of Kirganelia reticulata extract on Human Embryonic Kidney cells with evidence on morphological changes. J App Pharm Sci, 2018; 8(09): 114-118. 


\section{SUPPLEMENTARY INFORMATION}

Data summary showing confluency percentage of HEK-293 cells post-treatment with K. reticulata extract.

\begin{tabular}{|c|c|c|c|c|c|}
\hline & 0 hours & 1 hour & 2 hours & 3 hours & 24 hour \\
\hline $0 \mu \mathrm{g} / \mathrm{mL}$ & 60 & 60 & 60 & 60 & 90 \\
\hline $10 \mu \mathrm{g} / \mathrm{mL}$ & 60 & 60 & 60 & 60 & 90 \\
\hline $25 \mu \mathrm{g} / \mathrm{mL}$ & 60 & 60 & 60 & 60 & 90 \\
\hline $50 \mu \mathrm{g} / \mathrm{mL}$ & 60 & 60 & 60 & 60 & 80 \\
\hline $100 \mu \mathrm{g} / \mathrm{mL}$ & 60 & 60 & 50 & 50 & 30 \\
\hline $250 \mu \mathrm{g} / \mathrm{mL}$ & 60 & 50 & 40 & 40 & 10 \\
\hline $500 \mu \mathrm{g} / \mathrm{mL}$ & 60 & 30 & 20 & 20 & 0 \\
\hline $1000 \mu \mathrm{g} / \mathrm{mL}$ & 60 & 30 & 10 & 10 & 0 \\
\hline
\end{tabular}

